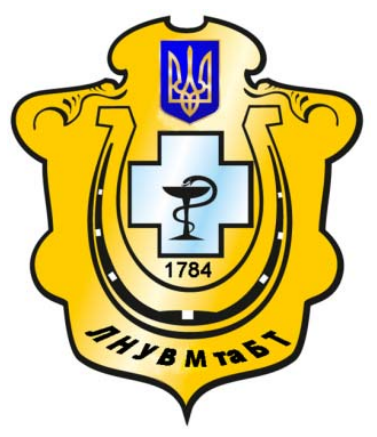

Науковий вісник Львівського національного університету ветеринарної медицини та біотехнологій імені С.3. Гжицького

Scientific Messenger of Lviv National University of Veterinary Medicine and Biotechnologies named after S.Z. Gzhytskyj

doi:10.15421/nvlvet7619

ISSN 2519-2701 print

ISSN 2518-1327 online

$\underline{\text { http://nvlvet.com.ua/ }}$

\title{
Сучасний стан та перспективи розвитку світового ринку м'яса птиці
}

\author{
С.В. Сендецька \\ svitlana.sendetska@gmail.com
}

Львівський національний університет ветеринарної медицини та біотехнологій імені С.3. Гжицького, вул. Пекарська, 50, м. Львів, 79010, Україна

В статті показано, щзо виробництво м'яса птиці є тваринницькою галуззю, яка в світі демонструє найвищі темпи зростання обсягів виробництва за минулі десять років порівняно з іншими галузями тваринництва. Визначено найбільших світових виробників бройлерного м'яса, якими є США, Бразилія, Китай, краӥни Свропейського Союзу, Індія, щчо разом забезпечують понад дві третини всього світового виробництва цьього виду продукиії. Украӥна займає 19 позицію з обсягами виробництва у 2016 р. понад 1,05 млн т.

Показано, що основними експортерами бройлерного м'яса є Бразилія, США, краӥни Євросоюзу, Тайланд і Китай. Визначено, щуо найбільшими імпортерами бройлерного м'яса на світовому ринку є Японія, Мексика, Саудівська Аравія. Украӥна займає сьому позицію в світі за обсягами експорту бройлерного м'яса. Украӥнські виробники у 2016 р. збільшили експортні поставки м'яса птиці майже на 80 тис. т. Основний вектор поставок був спрямований на азійсько-африканський ринок. Обсяги імпорту курячого м'яса в Україну також зросли трохи більше як на 20 тис. т. В Украйну ввозиться здебільшого дешева низькоякісна продукиія.

Ключові слова: м'ясо птииі, світовий ринок, обсяги виробниитва, експорт, імпорт, м'ясо бройлерів.

\section{Современное состояние и перспективы развития мирового рынка мяса птицы}

\author{
С.В. Сендецкая \\ svitlana.sendetska@gmail.com
}

\begin{abstract}
Львовский национальный университет ветеринарной медицины и биотехнологий имени С.3. Гжицкого, ул. Пекарская, 50, г. Львов, 79010, Украина
\end{abstract}

В статье показано, что производство мяса птииь является животноводческой отраслью, которая в мире демонстрирует высокие темпы роста объемов производства за прочедшие десять лет по сравнению с другими отраслями животноводства. Определены крупнейшие мировые производители бройлерного мяса, которыми являются США, Бразилия, Китай, страны Европейского Союза, Индия. Они вместе обеспечивают более двух третей всего мирового производства этого вида продукиии. Украина занимает 19 позицию с объемами производства в 2016 г. более 1,05 млн т.

Показано, что основныли экспортерами бройлерного мяса являются Бразилия, США, страны Евросоюза, Таиланд и Китай. Определено, что крупнейшими импортерами бройлерного мяса на мировом рынке является Япония, Мексика, Саудовская Аравия. Украина занимает седьмую позичию в мире по объемам экспорта бройлерного мяса. Украинские производители в 2016 увеличили экспортные поставки мяса птицы почти на 80 тыс. т. Основной вектор поставок был направлен на азиатско-африканский рынок. Объемы импорта куриного мяса в Украине также выросли более чем на 20 тыс. т. В Украину ввозится в основном дешевая низкокачественная продукиия.

Ключевые слова: мясо птицы, мировой рынок, объемы производства, экспорт, импорт, мясо бройлеров.

Citation:

Sendetska, S. (2017). The current state and development prospects of the global poultry meat market. Scientific Messenger LNUVMBT named after S.Z. Gzhytskyj, 19(76), 96-99. 


\title{
The current state and development prospects of the global poultry meat market
}

\author{
S. Sendetska \\ svitlana.sendetska@gmail.com \\ Lviv National University of Veterinary Medicine and Biotechnologies named after S.Z. Gzhytskyi, \\ Pekarska Str., 50, Lviv, 79010, Ukraine;
}

This article considers that the poultry meat production is the livestock industry which has the world's highest rates of production volume growth over the past ten years compared with other sectors of animal husbandry. Assuming current trends to be continued in 2020 it will be produced about 93.4 million tons of broiler meat in the world but it still will remain in the second place comparatively to the production volume of the pork meat.

It is determined the world's largest producers of broiler meat which are USA, Brazil, China, European Union countries, India. Together they produce more than two-thirds of world production of this type of product. In this ranking Ukraine occupies the 19th place of production volume that is more than 1.05 million tons according to data of 2016.

It is shown that the main broiler meat exporters are Brazil, the United States, European Union countries, Thailand and China. By 2016 they exported 9843 thousand tons of meat products. The largest exporter is Brazil which exports about 30\% of the whole production. The US exports 16-19\%. The feature of the US poultry market is high popularity of the turkey meat besides to the chicken meat. Also the US mostly consumes the white chicken meat and exports the dark chicken meat.

It is also determined that the largest importers of the broiler meat in the world market is Japan, Mexico, Saudi Arabia. Ukraine occupies the 7th place of export volume of the broiler meat in the world. Ukrainian producers increased export of the poultry meat by almost 80 thousand tons in 2016. The main supply vector was directed to the Asia-African market. Ukrainian imported volume of the poultry meat is also increased slightly more than on the 20th thousand tons. Ukraine mainly imports cheap low-quality production.

Key words: poultry meat, the world market, production volume, export, import, broiler meat.

\section{Ветуі}

Промислове птахівництво - одна 3 небагатьох галузей тваринництва, яка дуже стрімко розвивається і $\epsilon$ вагомою складовою у виробництві м'яса та м'ясних продуктів в Україні. За минулі 10 років обсяги виробництва м'яса птиці подвоїлися і становили у 2015 р. 1157 тис. т. Зростання обсягів виробництва м'яса птиці суттєво вплинуло на його експорт, який за минулі 10 років зріс майже в 50 разів. Україна поступово зміцнює свої позиції серед найбільших виробників та експортерів пташиного м'яса, крім того, у зв'язку 3 військовою агресією на Сході вона втратила значні ринки збуту в Росії. 3 огляду на це дослідження світових тенденцій на ринку м'яса птиці $є$ актуальним.

Метою даної статті є аналіз світового ринку м'яса бройлерів, перспектив його розвитку, визначення місця України на цьому ринку, перспективних ринків збуту продукції птахівництва для нашої держави.

\section{Матеріали і методи досліджень}

В даному дослідженні застосовувалися загальнонаукові, маркетингові та графічні методи дослідження, дані статистичної звітності, Інтернет-ресурси.

\section{Результати та їх обговорення}

М'ясо птиці є другим за обсягами споживання м'ясом у світі. Світове виробництво бройлерного м'яса невпинно зростає. За десять минулих років воно зросло майже на 30\% і становило у 2016 р. 89,5 млн т. За цей же період виробництво яловичини і телятини практично не змінилося $(+3 \%)$, свинини - зросло на $15 \%$ (рис. 1).

У 2016 р. м'яса бройлерів вироблялося на 17\% менше, ніж свинини і майже на третину більше, ніж яловичини. При збереженні тенденцій останніх десяти років у 2020 р. у світі вироблятиметься близько 93,4 млн т м'яса бройлерів, проте воно залишатиметься на другому місці за обсягами виробництва після свинини

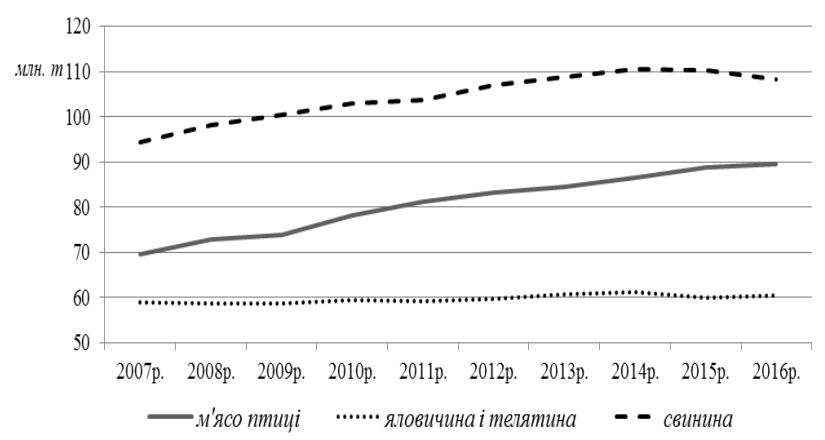

Рис. 1. Обсяги виробництва основних видів м'яса в світі

Джерело: за даними USDA

Основними виробниками м'яса птиці є США, Бразилія, Китай, країни Свропейського Союзу, Індія. Сумарно вони виготовляють понад дві третини всього світового виробництва цього виду продукції (табл. 1). Кожна $з$ цих країн щорічно нарощує обсяги виробництва м'яса бройлерів, але найбільших темпів зростання за минулі 10 років досягла Індія - 88\%. Ще вищими темпами за цей період зросло виробництво м'яса птиці в Україні - на 94\% (Derzhavna sluzhba statystyky Ukrai'ny), проте Україна поки що входить лише в топ20 виробників м'яса бройлерів, займаючи 19 позицію 3 обсягами виробництва у 2016 p. 1,05 млн т (IndexMundi, 2017). Бразилія лише у 2016 р. Змогла перевищити Китай за обсягами виробництва м'яса птиці, зайнявши другу позицію у світовому рейтингу. 
Необхідно зазначити, що динаміка світового виробництва м'яса птиці безпосередньо залежить від епідеміологічної ситуації. Світові пандемії, такі як пташиний грип, сальмонельоз тощо суттєво позначаються на позиціях країн-виробників і вимагають особли- вих заходів для подолання їх наслідків. Санітарні та фітосанітарні заходи $є$ також одним із ефективних засобів регулювання міжнародної торгівлі та захисту внутрішніх ринків.

Обсяги виробництва м'яса бройлерів країнами, які с найбільшими його виробниками

\begin{tabular}{|l|c|c|c|c|c|c|c|}
\hline \multicolumn{1}{|c|}{ Країна } & $2007 \mathrm{p}$. & $2010 \mathrm{p}$. & $2013 \mathrm{p}$. & $2014 \mathrm{p}$. & $2015 \mathrm{p}$. & $2016 \mathrm{p}$. & $\begin{array}{c}2016 \mathrm{p} . \mathbf{y} \% \\
\text { до 2007 p. }\end{array}$ \\
\hline США & 16,226 & 16,563 & 16,976 & 17,306 & 17,971 & 18,283 & 113 \\
\hline Бразилія & 10,305 & 12,312 & 12,308 & 12,692 & 13,146 & 13,605 & 132 \\
\hline Китай & 11,291 & 12,55 & 13,35 & 13 & 13,4 & 12,7 & 112 \\
\hline Країни СС & 8,32 & 9,202 & 10,05 & 10,45 & 10,81 & 11,07 & 133 \\
\hline Індія & 2,24 & 2,65 & 3,45 & 3,725 & 3,9 & 4,2 & 188 \\
\hline
\end{tabular}

Джерело: за даними USDA.

Основними експортерами бройлерного м'яса є Бразилія, США, країни Євросоюзу, Таїланд і Китай. За 2016 р. вони експортували 9843 тис. т м'ясної продукції. Найбільший експортер - Бразилія - експортує близько 30\% всієї виготовленої продукції, США - 16$19 \%$.

Розвиток м'ясного птахівництва в США призвів не лише до повного забезпечення населення м'ясом птиці, а й до другого місця у світі з експорту цього виду продукції. Зростання виробництва м'яса бройлерів тут зумовлене активним попитом населення через порівняно низькі ціни на нього (порівняно $з$ іншими видами м'яса), його високими дієтичними характеристиками, певними уявленнями американців про здорову іжу, а також через масове використання м'яса птиці переробною промисловістю для виробництва напівфабрикатів для швидкого приготування їжі як в домашніх умовах, так і у відповідних закладах громадського харчування (Romanenko and Evdokimova, 2014).

Основним фактором інтенсивного розвитку птахівництва в США стало використання вертикальної інтеграції - організаційних зв'язків між виробниками сировини, кормів, переробниками і сферою реалізації. Гіганти-інтегратори, які координують і контролюють всі стадії виробництва м'яса птиці різних видів, мають власні інкубатори, забійні, переробні цехи, а також підприємства з виробництва кормів. Особливістю ринку м'яса птиці в США є та обставина, що поряд 3 курячим м'ясом високою популярністю користується i м'ясо індика. Також США є здебільшого споживачем білого м'яса і експортером темного м'яса курей. Таким чином, неординарність даного ринку полягає в тому, що один з спільних продуктів випускається для внутрішнього ринку, а інший - на зовнішній ринок (Romanenko and Evdokimova, 2014).

Україна входить в десятку найбільших експортерів бройлерного м'яса, займаючи у 2016 р. в ній сьому позицію 3 обсягами експорту 240 тис. т. Україна у 2016 р. році експортувала майже половину вивезеної продукції до країн Азії (106 тис т, в т. ч. до Іраку 64 тис. т), 47,4 та 49 тис. т - до країн СНД та Африки відповідно. Оскільки Євросоюз $є$ одним 3 крупних виробників та експортерів м'яса птиці, нашій державі не варто покладати великі надії на європейський ринок, що в значній мірі й пояснює малі експортні квоти
(36 тис. т у 2016 р.) на ввіз українського бройлерного м'яса до країн Євросоюзу. Більш привабливим для українських експортерів $є$ азійський і африканський ринки. Саме туди спрямовані основні світові експортні потоки м'яса птиці.

Найбільшими імпортерами бройлерного м'яса на світовому ринку є Японія, Мексика, Саудівська Аравія, країни Свросоюзу, Ірак, Південна Африка, Китай, Гонконг, Об'єднані Арабські Емірати, Філіппіни. На ці країни припадає 66\% всього світового імпорту м'яса бройлерів, а найбільший імпортер - Японія купує близько 10\% всієї імпортованої продукції.

У 2016 р. Україна збільшила експортні поставки м'яса птиці майже на 80 тис. т, обсяги ж імпортованого курячого м'яса в Україну також зросли трохи більше як на 20 тис. т. Проте в Україну ввозиться здебільшого дешева низькоякісна продукція. За даними Державної служби статистики за 2016 р. середня митна вартість 1 кг вивезеного м'яса птиці становила 1,22 дол. США, а ввезеного - всього 0,41 дол. США.

\section{Висновки}

За десять минулих років світове виробництво м'яса бройлерів зросло майже на $30 \%$ і становило у 2016 р. 89,5 млн т. Основними виробниками та експортерами м'яса птиці є США, Бразилія, Китай, країни Європейського Союзу. Особливістю ринку м'яса птиці США полягає в тому, що тут здебільшого споживають біле м'ясо і експортують в основному темне м'ясо курей. Найбільшими імпортерами бройлерного м'яса на світовому ринку є Японія, Мексика, Саудівська Аравія. Україна займає сьому позицію в світі за обсягами експорту бройлерного м'яса. Українські виробники у 2016 р. збільшили експортні поставки м'яса птиці майже на 80 тис. т. Основний вектор поставок був спрямований на азійсько-африканський ринок. Обсяги імпорту курячого м'яса в Україну також зросли трохи більше як на 20 тис. т. В Україну ввозиться здебільшого дешева низькоякісна продукція.

Перспективи подальших досліджень. Дослідження тенденцій та перспектив розвитку ринку м'яса птиці $з$ урахуванням умов, які динамічно змінюються. 


\section{Бібліографічні посилання}

Derzhavna sluzhba statystyky Ukrai'ny [Elektronny] resurs]. - Rezhym dostupu: http://www.ukrstat.gov.ua (in Ukrainian).

Romanenko, I.A., Evdokimova, H.E. (2014). Gosudarstvennoe regulirovanie rynka ptich'ego mjasa v osnovnyh stranah-proizvoditeljah. - Rezhim dostupa: http://farmanimals.ru/articles/109/3698 (in Russian).

United States Department of Agriculture Foreign Agricultural Service [Electronic resource]. - Access: https://apps.fas.usda.gov/psdonline/app/index.html\#/a $\mathrm{pp} /$ home.

IndexMundi (2017). [Electronic resource]. - Access: https://www.indexmundi.com.

Стаття надійшла до редакиії 13.03.2017 